UDC $628.345=111$

\author{
${ }^{[0000-0002-5937-167 \times]}$ T. V. Solodovnik, associate professor \\ of the department of chemical technology and water treatment, \\ V. S. Kultenko, $M$. Sc.,
}

${ }^{[0000-0002-3432-4250]}$ A. A. Slis, Ph. D. student of the department of chemical technology and water treatment

Cherkasy State Technological University

Shevchenko blvd, 460, Cherkasy, 18006, Ukraine

\title{
RESEARCH ON THE EFFICIENCY OF USE OF NATURAL POLYMER FLOCCULANTS IN THE PROCESS OF WATER SOLUTION PURIFICATION
}

Natural flocculants are studied in the processes of water solution purification using the method of Jar-test. Experimental part of the work involves the research of different flocculants for the purification of colored water. The aim of this study is to determine the efficacy and optimal doses of flocculants in combination with aluminum sulfate. The flocculants such as chitosan, sodium alginate, starch and polyacrylamide are used for researching. As a coagulant, $\mathrm{Al}_{2}\left(\mathrm{SO}_{4}\right)_{3} \cdot 18 \mathrm{H}_{2} \mathrm{O}$ with a concentration of $10 \%$ is used. It has been established that chitosan is the most effective flocculation reagent. It is explored that such factors as the dosage of reagents, chemical nature of links and the composition of polymer macromolecules, physical and chemical parameters of the process and the concentration of reagents influence the flocculation process. The optimal conditions for carrying out the process of flocculation are established.

Keywords: flocculants, polymers, chitosan, coagulation, Jar-test.

Introduction. Water purification efficiency has a significant place in the national economy of the country, so great importance is given to substances that purify water. Color is one of the most important parameters of drinking water quality control. A combination of chemical and physical processes consisting of coagulation and flocculation followed by precipitation and filtration is used to purify the water. Recently using natural biopolymers as flocculants in water purification is growing in popularity [1-3]. Polymers are water soluble macromolecular compounds, which, when introduced into disperse systems, are adsorbed or chemically bind to the surface of particles of the dispersed phase and combine particles into agglomerates (flocs), facilitating their rapid precipitation. The using of metal coagulants with flocculants makes it possible to expand the optimal coagulation zones ( $\mathrm{pH}$ and temperature), reduce the consumption of coagulants, increase the reliability and performance of wastewater treatment facilities. Organic polymers have the ability to destabilize the disperse system, that is why some flocculants may be used without adding of metal coagulants [4]. Natural polymers are activated silica, starches, seeds from the Moringa Oleifera trees, chitosan, guar gums, tannins and sodium alginate. Biopolymers are virtually non-toxic and more environmentally friendly compared to synthetic polymers [6-12].
Therefore, it is quite important to research physical and chemical properties of natural flocculants and identify ways of their prospective using.

Methods and materials. In the experiment, $\mathrm{Al}_{2}\left(\mathrm{SO}_{4}\right)_{3} \cdot 18 \mathrm{H}_{2} \mathrm{O}$ was used as coagulant and potato starch, sodium alginate (production of "Aldrich"), acrylamide cationic AK-636r (brand KP-555), chitosan (manufactured by ZAO Bioprogress with a degree of deacetylation of $82 \%$ ) were used as flocculants. To prepare solution of coagulant, $10 \mathrm{~g}$ of $\mathrm{Al}_{2}\left(\mathrm{SO}_{4}\right)_{3} \cdot 18 \mathrm{H}_{2} \mathrm{O}$ was dissolved in $100 \mathrm{ml}$ of distilled water, thus obtaining a concentration of $10 \%$ coagulant solution. Solution of chitosan was prepared by dissolving $1 \mathrm{~g}$ of chitosan in $1 \mathrm{ml}$ of acetic acid and diluted in $100 \mathrm{ml}$ of distilled water. The resulting solution was stirred with a magnetic stirrer until chitosan dissolves completely. A solution of sodium alginate and polyacrylamide were prepared by diluting $1 \mathrm{~g}$ of sodium alginate and polyacrylamide in $100 \mathrm{ml}$ of distilled water. The resulting solutions were stirred on a magnetic stirrer to completely dissolve sodium alginate and polyacrylamide. The starch solution was prepared by diluting $1 \mathrm{~g}$ of starch in $5 \mathrm{ml}$ of distilled water. The prepared mixture was poured into boiling distilled water $(100 \mathrm{ml})$ and boiled for 2 minutes. The concentration of flocculants in the solution was $1 \%$.

For the preparation of water samples, a dye was used - active blue 3SWT and distilled water. 
To prepare color solutions, $0.1 \mathrm{~g}$ of dye was dissolved in 11 of distilled water and mixed on a magnetic stirrer at a rate of $20 \mathrm{rpm}$. This solution was used as a starting material for preparation of model solutions with a dye concentration of $0.02 \mathrm{~g} / \mathrm{l}$. In order to create solutions, close to the industrial effluent, hardness salts: $\mathrm{MgSO}_{4} \cdot 7 \mathrm{H}_{2} \mathrm{O}$ and $\mathrm{CaCl}_{2} \cdot 5 \mathrm{H}_{2} \mathrm{O}$ were added.

For experimental research, a laboratory unit for Jar test was used, the scheme of which is shown in Figure 1. Jar test unit consists of
6 laboratory glasses of 11,6 mechanical stirrers with adjustable rotation speed and mixing time. These parameters are regulated by using Flocculator 2000. The rotation speed is from 10 to 140 revolutions per minute. The maximum mixing time is 60 minutes. The device is additionally equipped with a $\mathrm{pH}$ electrode to control the $\mathrm{pH}$ in water samples. The $\mathrm{pH}$ of water sample was adjusted using $\mathrm{HCl}$ and $\mathrm{NaOH}$ solutions with concentration $0.1 \mathrm{M}$.

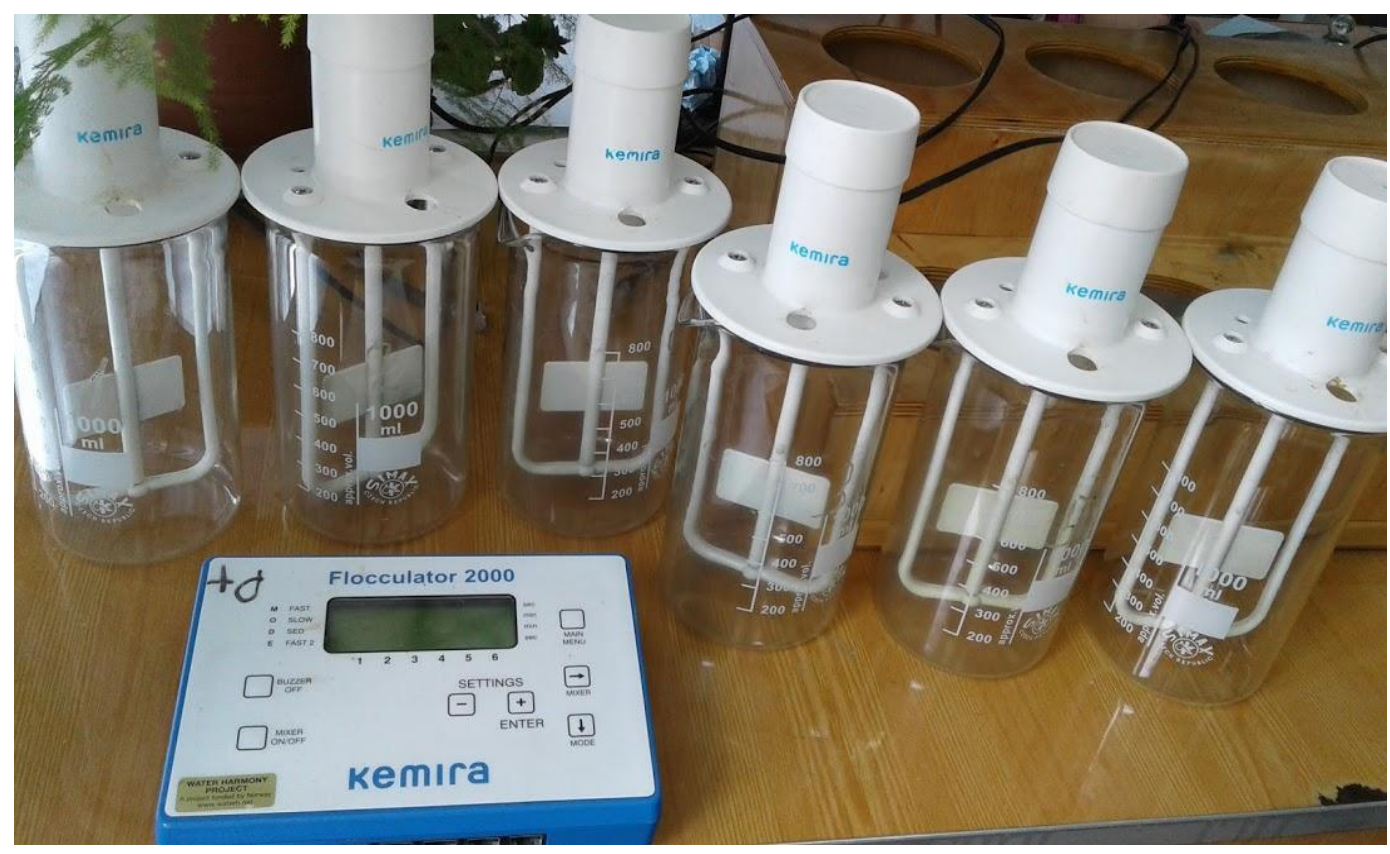

Figure 1 - Laboratory equipment for Jar tests

Experiment was conducted at $140 \mathrm{rpm}$ of mixing rate for 3 min after adding coagulant or flocculant then the speed was reduced to $50 \mathrm{rpm}$ for $10 \mathrm{~min}$ and $20 \mathrm{~min}$ of settling time.

The color of the solutions was investigated using a spectrophotometer UV-5800 (Shanghai, China).

The removal efficiency of the dye (RE) was calculated using the following equation:

$$
R E(\%)=\left[1-\frac{D_{F}}{D_{I}}\right] \cdot 100 \%
$$

where $D_{I}$ is the initial optical density and $D_{F}$ is the final optical density of colored solutions.

Results and discussion. Since chitosan is a cationic polymer, it has the property of neutralizing the charge due to its personal charge. Chitosan has a high charge density. In addition, the charge density of the polymer rises when the adsorption polymer is increased [5]. In this way, this means the rapid destabilization of particles and therefore, chitosan may be used without adding of metal coagulants.

The objective of the first stage of the research was to determine the optimal dose of chitosan. The results are presented in Figure 2. The effect of the dosage was analyzed at $\mathrm{pH} 7.5$ and temperature $20 \mathrm{C}$. The experiment was carried out by changing the concentration of chitosan from $5 \mathrm{mg} / \mathrm{l}$ to $35 \mathrm{mg} / \mathrm{l}$. It can be observed from the Figure 2 that at the dose of chitosan $30 \mathrm{mg} / \mathrm{l}$ the removal efficiency of the dye is equal to $80 \%$, this is the best result among other doses. The velocity of sedimentation of the flakes was $0.025 \mathrm{~mm} / \mathrm{s}$. This is due to the fact that at such concentration there is a rapid destabilization of particles. Thus, an optimal dose of chitosan was determined, which was $30 \mathrm{mg} / \mathrm{l}$. 


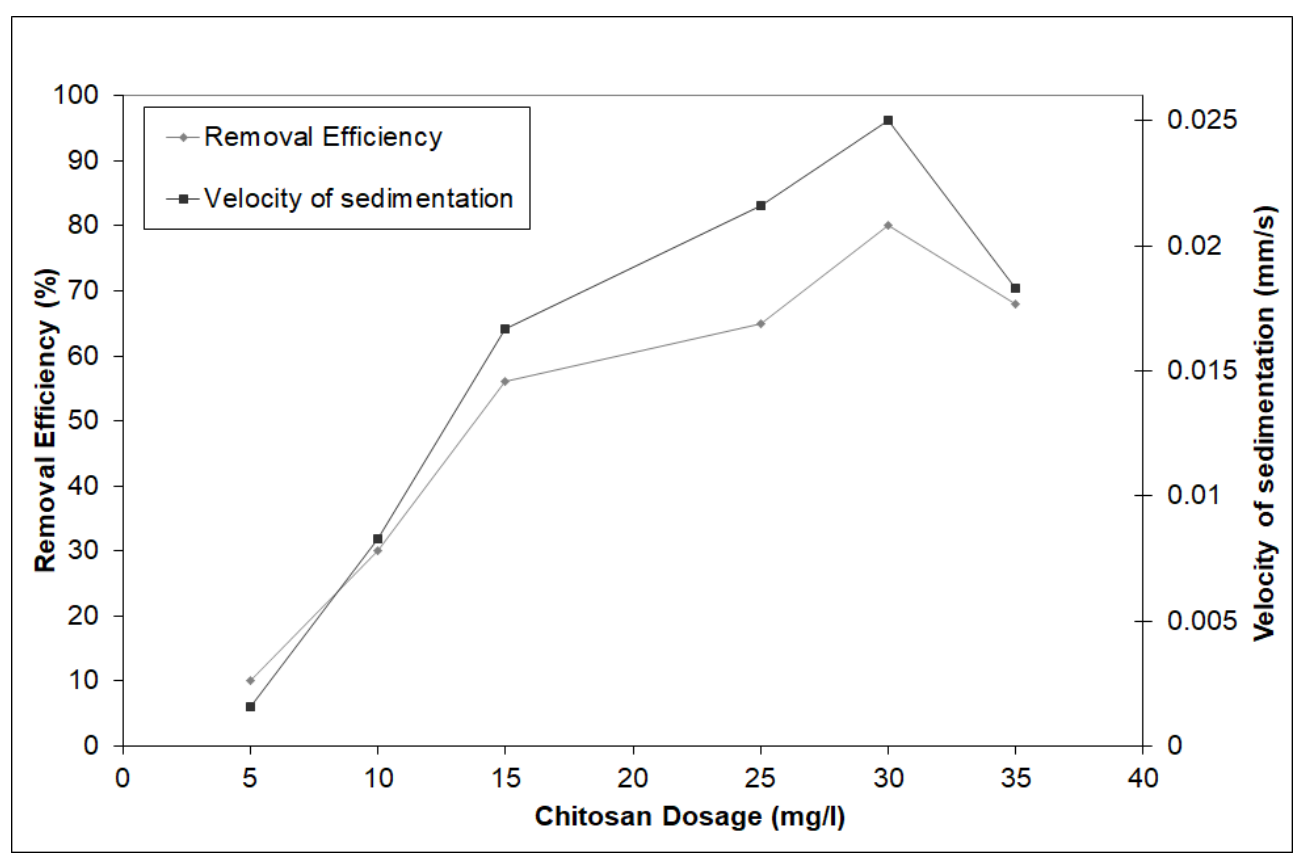

Figure 2 - Effects of chitosan dosage on removal efficiency and velocity of sedimentation without coagulant

The next stage of the experiment served to determine the optimal dose of chitosan in combination with $\mathrm{Al}_{2}\left(\mathrm{SO}_{4}\right)_{3} \cdot 18 \mathrm{H}_{2} \mathrm{O}$ coagulant at $\mathrm{pH} 7.5$ and $20 \mathrm{C}$. The experimental results are shown in Figure 3. The dose of $\mathrm{Al}_{2}\left(\mathrm{SO}_{4}\right)_{3} \cdot 18 \mathrm{H}_{2} \mathrm{O} 40 \mathrm{mg} / \mathrm{l}$ was used. Dosage of chitosan varied from 5 to $35 \mathrm{mg} / \mathrm{l}$.

The using of chitosan in combination with aluminum sulfate leads to an increase in the efficiency of the flocculation process, to the forma- tion of denser flakes and their rapid sedimentation at a lower chitosan dose. When using aluminum sulfate as a coagulant, the optimal dose of chitosan decreased to $15 \mathrm{mg} / \mathrm{l}$. In addition, using of chitosan as a flocculant helps in the processes of coagulation and flocculation to reduce the residual $\mathrm{Al}^{3+}$ in purified water [2]. The optimal ratio of chitosan to aluminum coagulant was set to $1: 2.6$.

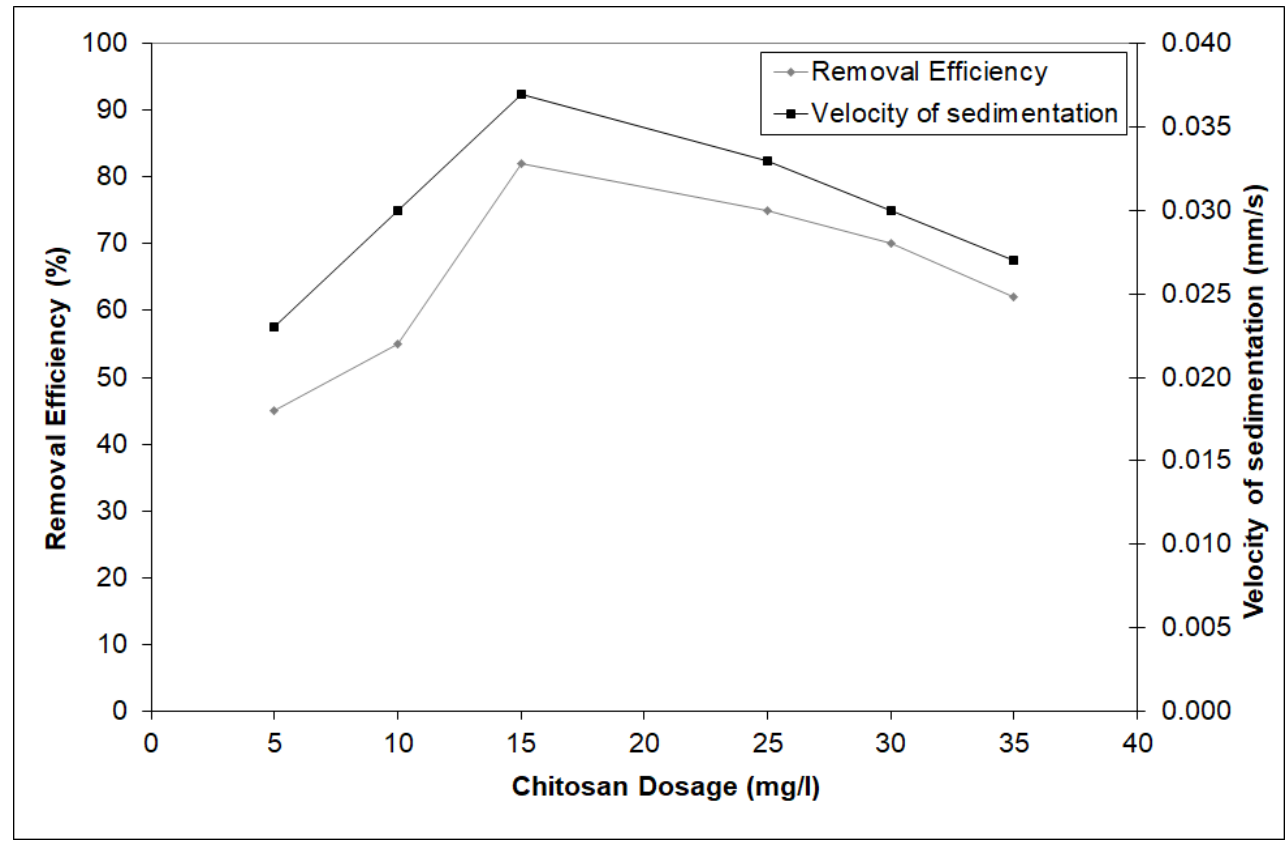

Figure 3 - Effects of chitosan dosage on removal efficiency and velocity of sedimentation with coagulant $\mathrm{Al}_{2}\left(\mathrm{SO}_{4}\right)_{3} \cdot \mathbf{1 8 H}_{2} \mathrm{O}$ 
The $\mathrm{pH}$ value not only affects the surface charge of flocculants, but also affects the stabilization of the suspension. In addition, the solubility of chitosan in aqueous solution depends on $\mathrm{pH}$. Thus, the study of $\mathrm{pH}$ is important for determining the optimal conditions for the treatment model solutions. The effect of $\mathrm{pH}$ was analyzed at previously determined optimum dosage of chitosan $30 \mathrm{mg} / \mathrm{l}$, for $\mathrm{pH}$ range varied from $\mathrm{pH} 2$ to $\mathrm{pH}$ 10. Experimental results are shown in Figure 4. By analyzing the removal efficiency of dye at different $\mathrm{pH}$ values, it can be stated that $\mathrm{pH}$ has an effect on coagulation and flocculation processes using chitosan. In addition, it was determined that increase in dye removal efficiency up to $82 \%$ occurs at $\mathrm{pH} 8$. Chitosan maintains the sorption ability and interacts electrostatically with anionic suspended particles in the model solution at $\mathrm{pH} 8$ [6].

Even in the study of $\mathrm{pH}$ influence on the complex aluminum sulfate-chitosan, the best result was observed at $\mathrm{pH} 8$. There is a complete hydrolysis of aluminum sulfate to form difficult soluble aluminum hydroxides that contribute to the adhesion of colloidal particles, and therefore better sedimentation of flakes at $\mathrm{pH}$ 8. In a higher $\mathrm{pH}$ range, the coagulant-flocculant system does not work efficiently, because when $\mathrm{pH}$ is higher than the optimal, there is a decrease in the ionization of chitosan and its solubility in water.

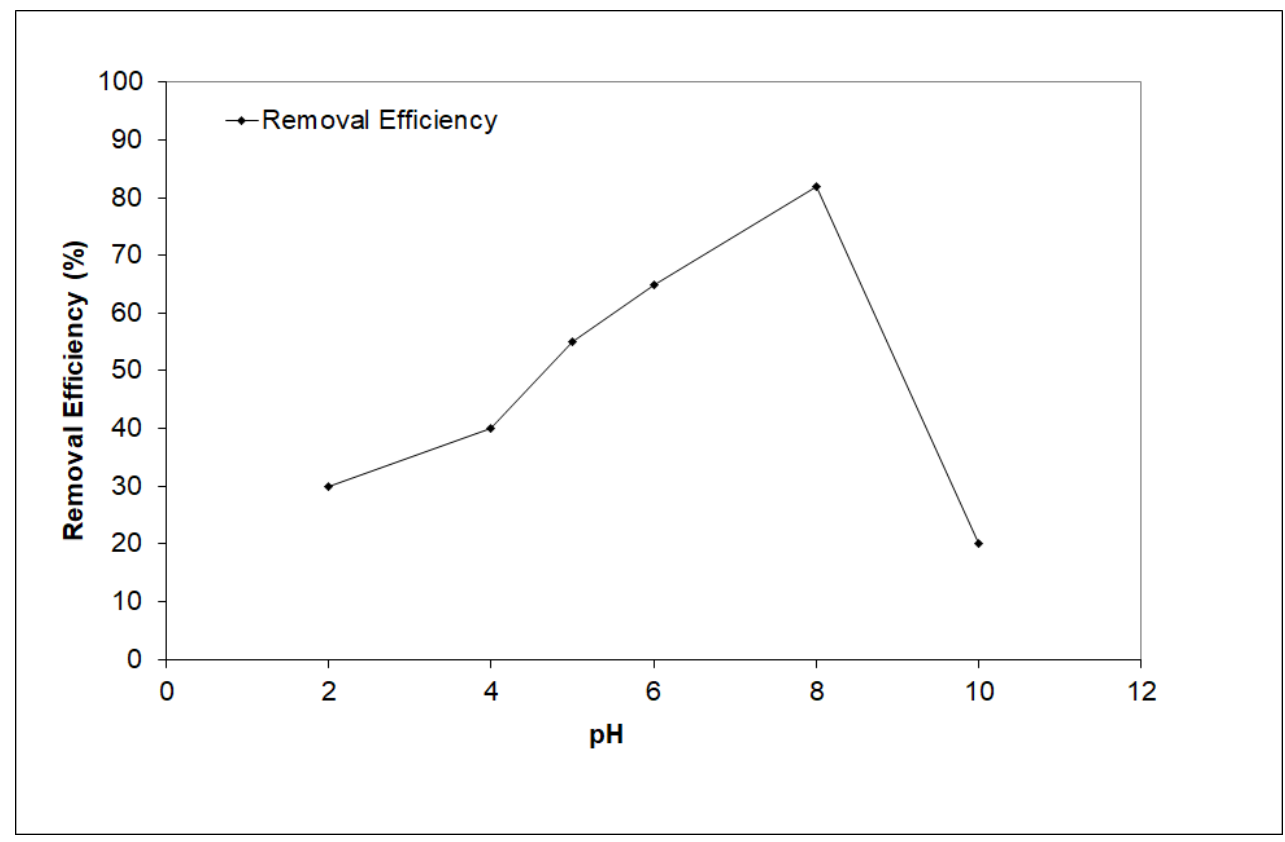

Figure 4 - Effect of pH on removal efficiency, using dose of chitosan $30 \mathrm{mg} / \mathrm{l}$ without coagulant

The next flocculant, which was studied, was sodium alginate. Since sodium alginate is anionic flocculant, it does not exhibit coagulating properties in water purification processes, such as chitosan. Therefore, in the study of the effectiveness of sodium alginate as a flocculant, an additional coagulant $\mathrm{Al}_{2}\left(\mathrm{SO}_{4}\right)_{3} \cdot 18 \mathrm{H}_{2} \mathrm{O}$ was used. The process of coagulation and flocculation was carried out at $\mathrm{pH} 7,5$ and temperature $20^{\circ} \mathrm{C}$. The concentration of sodium alginate was variated from $10 \mathrm{mg} / \mathrm{l}$ to $50 \mathrm{mg} / \mathrm{l}$. The dose of $\mathrm{Al}_{2}\left(\mathrm{SO}_{4}\right)_{3} \cdot 18 \mathrm{H}_{2} \mathrm{O} 40 \mathrm{mg} / \mathrm{l}$ was used. The results are shown in Figure 5. From the data, it was determined that the optimum dose of sodium alginate was $40 \mathrm{mg} / \mathrm{l}$, because at such dosage the better discoloration of solution was and removal efficiency of dye occured $74 \%$, and the fastest sedimentation of particles was $0.033 \mathrm{~mm} / \mathrm{c}$. The ratio of sodium alginate to aluminum coagulant was set to 1:1.

The finally flocculant, which was studied, was starch. The starch does not exhibit high flocculating properties, therefore, in order to improve its properties, copolymerization with acrylamide is used. Copolymerization is successfully used to make significant changes to the properties of solutions of many flocculants, such as starch, cellulose, synthetic polysaccharides, etc. [7]. This allows them to be more effective in the process of flocculation. 


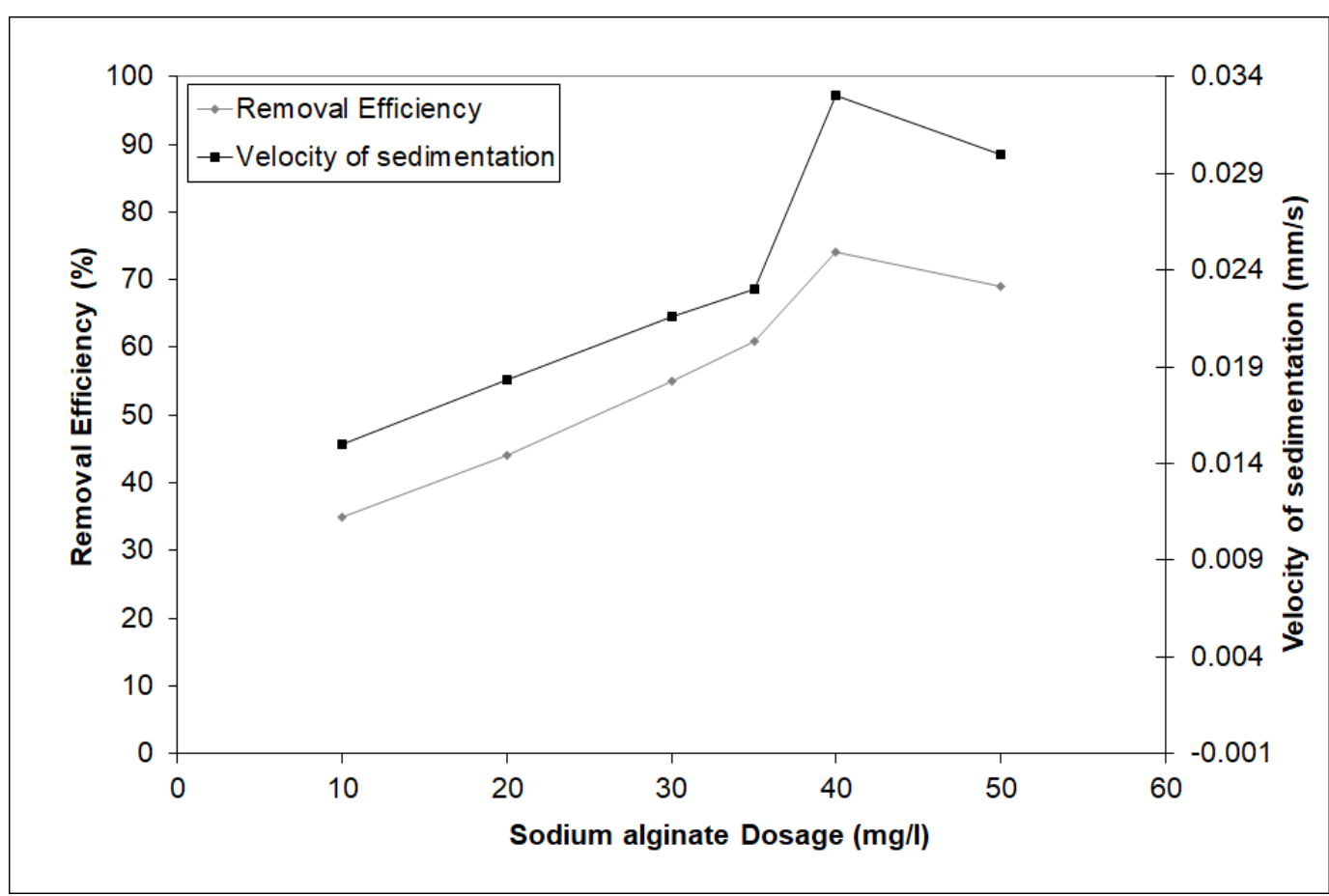

Figure 5 - Effects of sodium alginate dosage on removal efficiency and velocity of sedimentation with coagulant

As flocculants for research, starch and cationic acrylamide were used and as coagulant, $40 \mathrm{mg} / \mathrm{l}$ solution of $\mathrm{Al}_{2}\left(\mathrm{SO}_{4}\right)_{3} \cdot 18 \mathrm{H}_{2} \mathrm{O}$ was used. The process of coagulation and flocculation was carried out at $\mathrm{pH} 7.5$ and temperature $20^{\circ} \mathrm{C}$. The dose of acrylamide $10 \mathrm{mg} / \mathrm{l}$ was used. The concentration of starch was variated from $5 \mathrm{mg} / \mathrm{l}$ to $30 \mathrm{mg} / \mathrm{l}$. The results are presented in Figure 6.

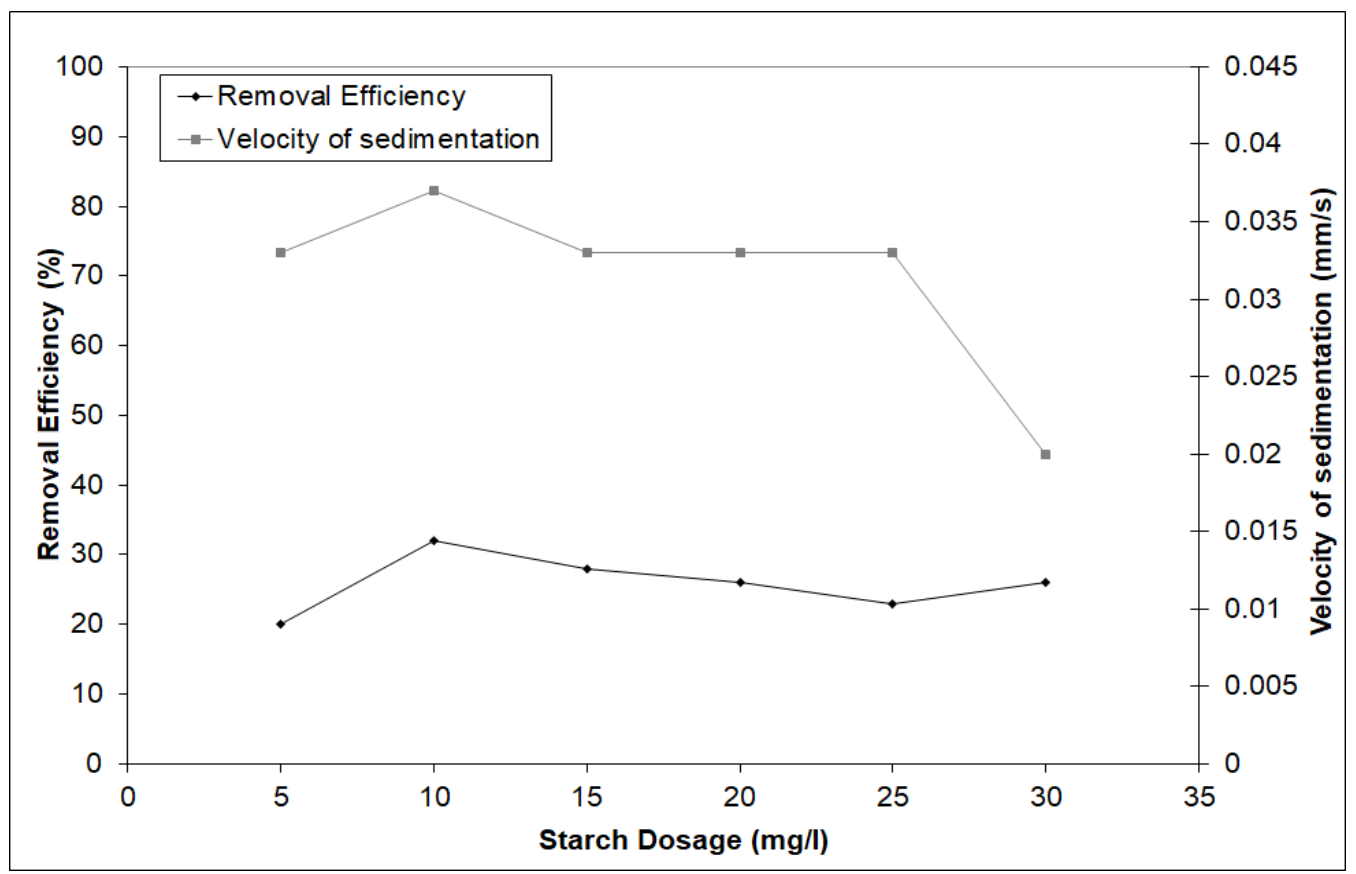

Figure 6 - Effects of starch dosage on removal efficiency and velocity of sedimentation, using acrylamide and coagulant 
The results at different concentrations of starch are almost identical, but according to the data, the optimum dose of starch was $10 \mathrm{mg} / \mathrm{l}$. At a dose of $10 \mathrm{mg} / \mathrm{l}$ the color level was 2 units, the velocity of sedimentation flakes was $0.037 \mathrm{~mm} / \mathrm{s}$. The optimal ratio of $\mathrm{Al}_{2}\left(\mathrm{SO}_{4}\right)_{3} \cdot 18 \mathrm{H}_{2} \mathrm{O}$ to starch and acrylamide was determined as 4:1:1. The starch is as an auxiliary reagent for increasing the efficiency of the flocculation process. It can be used in flocculation and coagulation processes in order to reduce the concentration of the main flocculant and accelerate the sedimentation of the flakes. Using starch with a coagulant is not appropriate, because it has poor flocculating properties. The starch works efficiently in the process of water treatment only when it is in combination with other flocculants in the role of copolymer.

Conclusions. The results of this study prove that in the research of natural flocculants, chitosan is the most effective flocculant in the process of purification of color solutions. It was shown that chitosan has a high charge density, successfully flocculates anionic suspended particles and is environmentally friendly. The use of complex aluminum sulfate-chitosan increases the formation of flakes and their sedimentation, reduces costs of coagulants and flocculant, reduces the residual $\mathrm{Al}^{3+}$ in purified water and increases the level of purification of color solutions.

\section{References}

[1] R. Fabris, C. W. K. Chow, and M. Drikas, "Evaluation of chitosan as a natural coagulant for drinking water treatment", Water Science and Technology, vol.61, no. 8, pp. 2119-2128, 2010.

[2] B. Bina, M. H. Mehdinejad, M. Nikaeen, and H. A. Movahedian, "Effectiveness of chitosan as natural coagulant aid in treating turbid waters", Iranian Journal of Environmental Health Science \& Engineering, vol. 6, no. 4, pp. 247-252, 2009.

[3] F. Renault, B. Sancey, P. M. Badot, and G. Crini, "Chitosan for coagulation/flocculation processes - an eco-friendly approach", European Polymer Journal, vol. 45, no. 5, pp. 1337-1348, 2009.

[4] I. M. Astrelin, and H. Ratnaweera, Physicalchemical methods of water treatment. Water resource management. Kiev: Project "Water harmony", 2015.

[5] A. L. Ahmad, S. Sumathi, and B. H. Hameed, "Coagulation of residue oil and suspended solid in palm oil mill effluent by chitosan, alum and PAC", Chemical Engineering Journal, vol. 118, no. 1-2, pp. 99105, 2006.

[6] J. Guzman, I. Saucedo, J. Revilla, R. Navarro, and E. Guibal, "Copper sorption by chitosan in the presence of citrate ions: influence of metal speciation on sorption mechanism and uptake capacities", International Journal of Biological Macromolecules, vol. 33, no. 1-3, pp. 57-65, 2003.

[7] M. J. Zohuriaan-Mehr, "New polysaccharide-g-polyacrylonitrile copolymers: synthesis and thermal characterization", Polymers for Advanced Technologies, vol. 14, no. 7, pp. 508-516, 2003.

[8] J. Li, S. Jiao, L. Zhong, J. Pan, and Q. Ma, "Optimizing coagulation and flocculation process for kaolinite suspension with chitosan", Colloids and Surfaces A: Physicochemical and Engineering Aspects, vol. 428, pp. 100-110, 2013.

[9] Z. Yang et al., "Cationic content effects of biodegradable amphoteric chitosan-based flocculants on the flocculation properties", Journal of Environmental Sciences, vol. 24, no. 8, pp. 1378-1385, 2012.

[10] Z. Yang et al., "Evaluation of a novel chitosan-based flocculant with high flocculation performance, low toxicity and good floc properties", Journal of Hazardous Materials, vol. 276, pp. 480-488, 2014.

[11] K. A. S. Meraz, S. M. P. Vargas, J. T. L. Maldonado, J. M. C. Bravo, M. T. O. Guzman, and E. A. L. Maldonado, "Eco-friendly innovation for nejayote coagulation-flocculation process using chitosan: Evaluation through Zeta $(\zeta)$ potential measurements", Chemical Engineering Journal, vol. 284, pp. 536-542, 2016.

[12] S. A. Fast, B. Kokabian, and V. G. Gude, "Chitosan enhanced coagulation of algal turbid waters - comparison between rapid mix and ultrasound coagulation methods", Chemical Engineering Journal, vol. 244, pp. 403-410, 2014. 
Т. В. Солодовнік, к.х.н., доцент кафедри хімічних технологій та водоочищення,

В. С. Культенко, магістр кафедри хімічних технологій та водоочищення,

А. А. Слісь, аспірант кафедри хімічних технологій та водоочищення

Черкаський державний технологічний університет

б-р Шевченка, 460, м. Черкаси, 18006, Україна

\section{ДОСЛІДЖЕННЯ ЕФЕКТИВНОСТІ ВИКОРИСТАННЯ ПРИРОДНИХ ПОЛІМЕРНИХ ФЛОКУЛЯНТІВ У ПРОЦЕСІ ОЧИЩЕННЯ ВОДНИХ РОЗЧИНІВ}

У роботі природні флокулянти досліджувалися в прочесах очищення водних розчинів методом Джар-тесту. Експериментальна частина роботи включала дослідження флокулянтів для очищення кольорових вод. Мета роботи - визначити ефективність і оптимальні дози флокулянтів у комплексі з сульфатом алюмінію. Для дослідження використано флокулянти, такі як хітозан, альгінат натрію, крохмаль та поліакриламід. Як коагулянт використовували $\mathrm{Al}_{2}\left(\mathrm{SO}_{4}\right)_{3} \cdot 18 \mathrm{H}_{2} \mathrm{O}$ з концентрачією $10 \%$. Для визначення оптимальної дози флокулянта використовувався Джар-тест, який дає можливість з великою точністю імітувати прочеси утворення пластівців, що йдуть на промислових установках фізико-хімічного очищення води. Досліджено, що такі фактори, як дозування реагентів, хімічна природа зв 'язків і склад полімерних макромолекул, фізичні й хімічні параметри прочесу та концентрація реагентів впливають на процес флокулящії. Встановлено, що хітозан є найбільш ефективним реагентом для флокуляиіі - як самостійно, так $і$ у поєднанні з сульфатом алюмінію. Визначено оптимальні умови для проведення процесу флокуляиії. Після проведення багаторазових досліджень встановлено, що максимальне поліпшення якості очищуваної води досягається при значеннях $p H=8, t=20$ С та використанні хітозану в комбіначії з сульфатом алюмінію у співвіднотенні 1:2,6 відповідно. Найбільша ефективність очищення забарвлених розчинів (близько 80 \%) досягалася при дозі

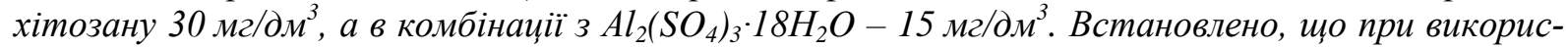
танні комплексного хітозан-сульфат алюмінію флокулянта збільшується швидкість утворення пластівиів та їх осідання, зменшуються витрати коагулянтів та флокулянтів, зменшується залишковий $\mathrm{Al}^{3+}$ в очищеній воді та підвищується рівень очищення кольорових розчинів.

Ключові слова: флокулянти, полімери, хітозан, коагулячія, Джар-тест.

Стаття надійшла 18.10.2019

Прийнято 04.01.2020

(C) Т. В. Солодовнік, В. С. Культенко, А. А. Слісь, 2020

DOI: $10.24025 / 2306-4412.1 .2020 .181072$ 